\title{
Robot Forklift Dengan Sensor Cahaya Sebagai Penentu Warna Barang Berbasis Mikrokontroler
}

\author{
M. Irmansyah ${ }^{1}$, Tuti Angraini ${ }^{2}$, Laras Novita ${ }^{3}$ \\ ${ }^{123}$ Jurusan Teknik Elektro Politeknik Negeri Padang \\ mirmansyah38@gmail.com \\ Kampus Politeknik Negeri Padang, Limau Manis Padang
}

\begin{abstract}
Forklift Robots With Light Sensors As Determinants Of Goods Color aims to help humans to move an item without having to lift the item and can reduce the occurrence of workplace accidents. Besides that, it can be applied to industry and save time in work. Robot forklifts are controlled by the Arduino Mega 2560 microcontroller to regulate the overall work of the robot. The photodioda light sensor will detect the item based on its color and the item will be lifted by a forklift using a DC motor, which then the robot will know where the destination of the item uses a line sensor and choose which path to use. After that the DC motor on the wheel will move along the path, the forklift on the robot will put the item when it reaches its destination. The robot is designed to only detect 2 pieces of color, namely red and black with 2 intersections that have been arranged in the program. The forklift robot will follow the black line, the ADC data is obtained when the sensor passes the black line ie 255 and the ADC data when it is off the lane which is about 31 to 97. The forklift will lift the goods with PWM 255 and when lowering the PWM goods from the forklift, 70 . Sensor photodioda light functions to detect the color of the item to be lifted by the forklift and the color of the goods consists of two colors, namely red with ADC data that is read 26 and black with ADC data that is read 512. The distance of the color sensor can detect the color of the item which is $3 \mathrm{~cm}$. The use of free wheels results in a less smooth or zigzag robot path.
\end{abstract}

Keywords: Forklifts, Microcontrollers, PWMs, DC motors, Light Sensors

\begin{abstract}
Abstrak - Robot Forklift Dengan Sensor Cahaya Sebagai Penentu Warna Barang bertujuan untuk membantu manusia dalam memindahkan suatu barang tanpa harus mengangkat barang tersebut dan dapat mengurangi terjadinya kecelakaan kerja. Disamping itu, agar dapat diaplikasikan pada industri serta menghemat waktu dalam pekerjaan. Robot forklift dikendalikan dengan mikrokontroller Arduino Mega 2560 untuk mengatur kerja keseluruhan dari robot. Sensor cahaya photodioda akan mendeteksi barang berdasarkan warnanya dan barang tersebut akan diangkat oleh forklift dengan menggunakan motor DC, yang kemudian robot ini akan mengetahui kemana tujuan dari barang tersebut menggunakan sensor garis dan memilih jalur mana yang akan digunakan. Setelah itu motor DC pada roda akan bergerak mengikuti jalur, forklift pada robot akan meletakkan barang tersebut ketika sampai pada tujuan. Robot dirancang hanya dapat mendeteksi 2 buah warna barang yaitu warna merah dan hitam dengan 2 buah persimpangan yang sudah diatur pada program. Robot forklift akan mengikuti jalur berwarna hitam, data ADC yang didapat saat sensor melewati jalur hitam yaitu 255 dan data ADC pada saat diluar jalur yaitu sekitar 31 sampai 97. Forklift akan mengangkat barang dengan PWM 255 dan disaat menurunkan barang PWM dari forklift yaitu 70. Sensor cahaya photodioda berfungsi untuk mendeteksi warna barang yang akan diangkat oleh forklift dan warna barang terdiri dari dua warna yaitu merah dengan data ADC yang terbaca 26 dan hitam dengan data ADC yang terbaca 512. Jarak sensor warna dapat mendeteksi warna barang yaitu $3 \mathrm{~cm}$. Penggunaan roda bebas mengakibatkan jalan robot kurang mulus atau zigzag.
\end{abstract}

Kata kunci: Forklift, Mikrokontroler, PWM, motor DC, Sensor Cahaya

(C)2017 Elektron Jurnal Ilmiah dengan ditemukannya mikrokontroller sebagai alat bantu pengendali otomatis. Alat elektronik yang dapat menggantikan peran manusia dalam bekerja adalah sistem penentu dan pemindah barang berdasarkan warna, dengan kajian dapat membantu meringankan pekerjaan manusia dalam memindahkan dan menyeleksi barang sesuai dengan warnanya. Forklift adalah alat berat yang berfungsi untuk bongkar muat atau pemindahan barang dari satu area ke area lain. Forklift yang banyak di gunakan di industri sekarang ini masih menggunakan kendali manual, maksud dari kendali manual disini adalah kerja forklift masih diatur oleh manusia atau operator. Agung Deni Saputra [1] dalam penelitiannya membuat prototipe 
robot forklift yang dikendalikan menggunakan teknologi Android untuk mengatur sistem kerja dari robot tersebut. Dimana kelemahan tugas akhir ini adalah tidak adannya spesifikasi barang yang akan diangkat, baik bentuk maupun warna barangnya. Serta pengendalian robot menggunakan Android masih tergolong sistem kendali manual yang melibatkan manusia atau operator. Menanggapi kelemahan dari prototipe robot forklift sebelumnnya, sehingga dibuatlah fungsi robot yang dapat memperkecil kecelakaan kerja dan pekerjaaan akan lebih efisien. Robot forklift kali ini menggunakan sensor cahaya Photodioda yang berfungsi untuk membedakan warna dari barang yang akan diangkat dan sensor garis sebagai penunjuk jalur yang akan dilalui oleh robot itu sendiri. Mikrokontroller yang digunakan adalah Arduino Mega 2560 dan berfungsi sebagai pengolah sinyal yang masuk, serta pengatur gerakan motor penggerak forklift dan sebagai penghasil PWM yang akan mengatur kecepatan dari motor penggerak dan motor pengangkat pada forklift. Dari latar belakang tersebut maka dikembangkan penelitian tentang Robot Forklift Dengan Sensor Cahaya Sebagai Penentu Warna Barang Berbasis Mikrokontroler. Dengan adanya sistem ini diharapkan dapat menghemat waktu pengantaran barang dan terhindar dari kecelakaan kerja.

\section{METODE PENELITIAN}

\section{A. Blok Diagram}

Secara umum perancangan sistem pada robot forklift dengan sensor cahaya sebagai penentu warna barang berbasis mikrokontroler dapat dilihat pada gambar 1 berikut:

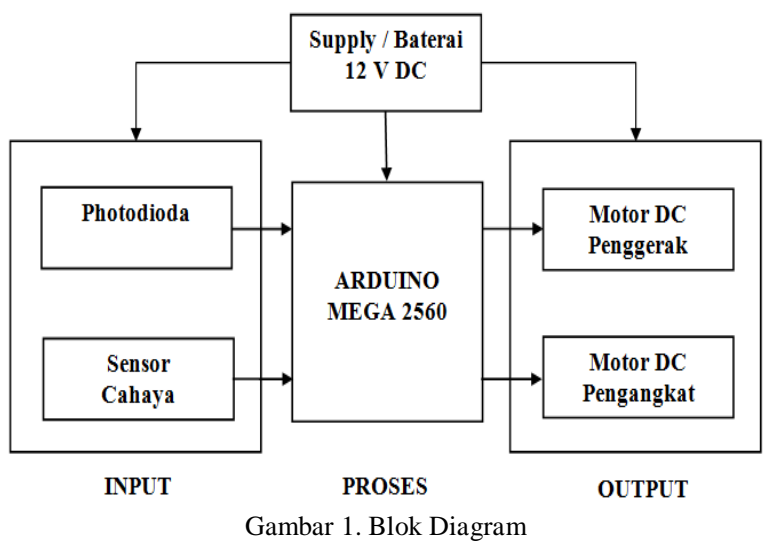

Prinsip kerja dari alat ini adalah robot dapat memindahkan barang sesuai dengan warnanya dan menghantarkan barang tersebut ke tempat yang sesuai dengan warna barang dengan mengikuti jalur. Warna barang yang dapat dideteksi oleh robot forklift ini adalah warna Merah dan Hitam. Untuk dapat mengangkut barang menuju tempat yang diinginkan maka alat ini digerakkan dengan menggunakan sebuah motor DC dan juga sensor garis Photodioda sebagai pendeteksi jalur. Sebelum beroperasi, robot forklift terlebih dahulu standby pada jalur yag telah dibuat, ketika robot dihidupkan dan diletakkan barang pada forklift maka ia akan mendeteksi warna barang yang akan diangkat. Arduino Mega2560 berperan sebagai pengontrol kerja keseluruhan dari robot ini dengan menggunakan sensor garis Photodioda dibagian depan dan belakang robot serta sensor cahaya photodiode untuk penentu warna barang. Motor DC akan bergerak mengikuti jalur, ketika sampai pada tujuan yang sesuai dengan warna barangnya maka forklift akan menurunkan barang tersebut.

\section{B. Perancangan Perangkat Keras (Hardware)}

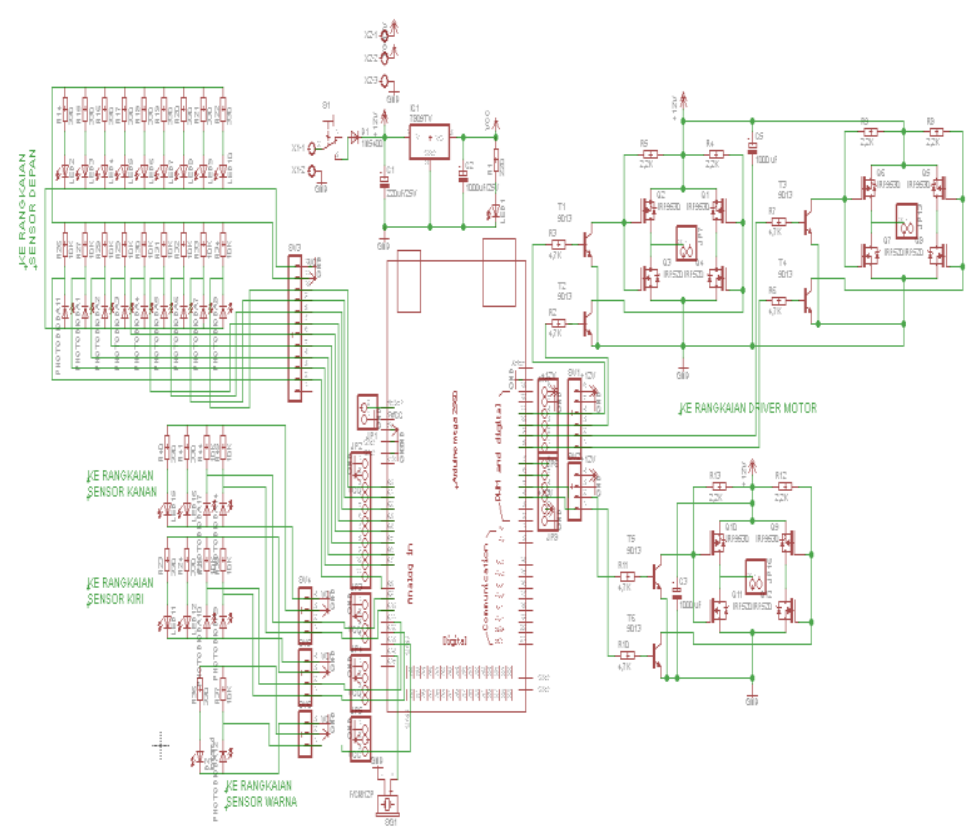

Gambar 2. Rangkaian Elektronika Keseluruhan Robot

Rangkaian sensor pada pembuatan penelitian ini terdapat 3 bagian yaitu sensor garis depan, sensor garis samping kiri dan sensor garis samping kanan, sebagaimana diperlihatkan pada gambar di bawah ini:

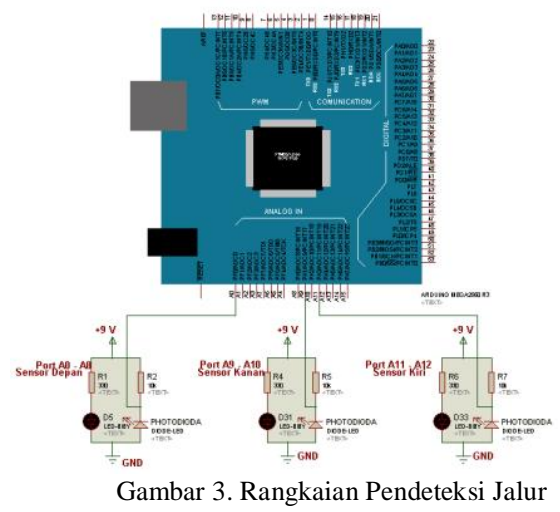

Sensor garis berfungsi untuk menentukan jalur mana yang akan dipilih untuk mengantar barang dengan tujuan yang tepat. Penggunaan LED superbright adalah sebagai pemberi pantulan cahaya sehingga 
cukup untuk menyuplai pantulan cahaya ke photodiode. Pada rangkaian ini port yang digunakan adalah port A0-A8 pada Arduino untuk sensor depan, port A9-A10 untuk sensor kanan dan port A11-A12 untuk sensor kiri. rangkaian sensor cahaya pada robot forklift ini menggunakan photodioda dan Infrared sebagai pengganti modul sensor warna, sebagaimana diperlihatkan pada gambar di bawah ini:

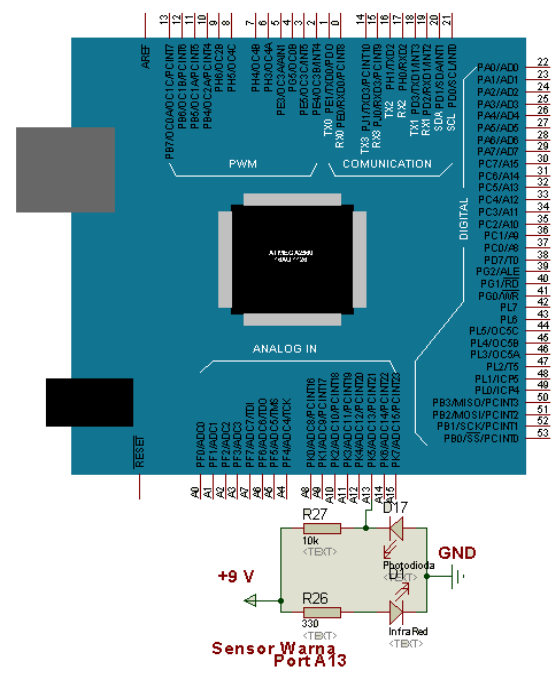

Gambar 4. Rangkaian Pendeteksi Warna

Sensor cahaya menggunakan photodioda dapat mendeteksi warna barang berdasarkan nilai ADC yang didapat. warna barang yang akan di deteksi oleh robot forklift adalah warna merah dan hitam. Port yang digunakan pada rangkaian ini adalah port A13. Pada bagian penggerak robot menggunakan dua buah rangkaian driver motor DC H-Bridge seperti yang terlihat pada gambar dibawah ini:

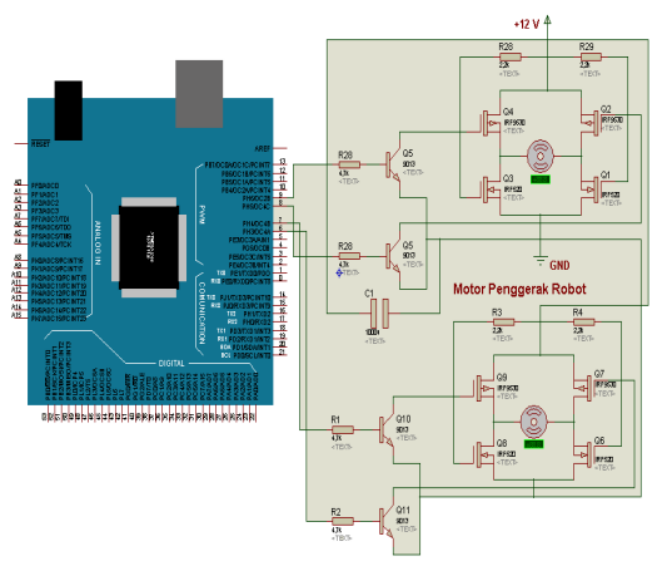

Gambar 5. Rangkaian Penggerak Robot

Rangkaian driver motor DC H-Bridge ini digunakan untuk menggerakan motor DC. Rangkaian driver motor DC ini menggunakan sistem bridge yang dibangun dengan 4 buah MOSFET yang mendapat picuan dari mikrokontroler. Selain itu juga digunakan
2 buah transistor yang berfungsi sebagai saklar dan beberapa buah resistor yang berfungsi untuk pembatas arus yang masuk pada rangkaian. Pada rangkaian ini Port yang digunakan adalah port PWM 6 dan 7 untuk penggerak roda kiri serta port PWM 8 dan 9.

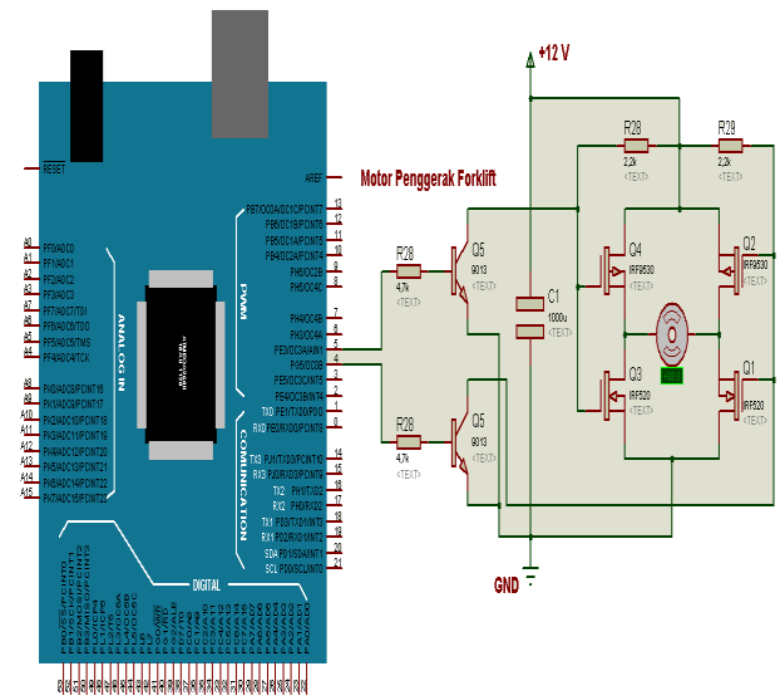

Gambar 6. Rangkaian Penggerak Forklift

Pada bagian penggerak forklift menggunakan satu buah rangkaian driver motor DC $\mathrm{H}$-Bridge seperti yang terlihat pada gambar 6. Nilai $P W M$ pada motor dc bagian penggerak forklift dapat dilihat pada tabel 1 .

Tabel 1. Nilai $P W M$ pada motor dc bagian penggerak forklift

\begin{tabular}{cccc}
\hline \multirow{2}{*}{ Perintah } & $\begin{array}{c}\text { Pin 4 } \\
\text { PWM }\end{array}$ & $\begin{array}{c}\text { Pin 5 } \\
\text { PWM }\end{array}$ & Motor \\
\hline Naik & 255 & 0 & $\mathrm{CW}$ \\
\hline Turun & 0 & 70 & $\mathrm{CCW}$ \\
\hline
\end{tabular}

\section{PWM ( Pulse Width Modulation)}

Dalam pembuatan robot ini, PWM dibangkitkan dengan menggunakan mikrokontroller. PWM yang digunakan bertujuan untuk mengatur kecepatan putaran motor DC yang akan menggerakan robot dan mengangkat beban. Untuk mengatur kecepatan motor saat robot forklift maju, mundur, up dan down. Seperti yang terlihat pada tabel 2. Mengingat bahwa hanya ada dua kondisi amplitude sinyal PWM (low dan high) sedangkan informasi PWM terletak pada perubahan lebar pulsanya, maka sinyal ini dapat dibangkitkan dengan mikrokontroller, yaitu dengan membuat program yang menghasilkan sinyal seperti PWM. Pembangkitan sinyal PWM dengan Mikrokontroller ini biasanya dipakai pada pengendalian motor DC, motor servo dan pengaturan nyala terang LED. 
Tabel 3. Nilai PWM pada Motor DC bagian Penggerak Robot

\begin{tabular}{|c|c|c|c|c|c|c|c|c|}
\hline Perintah & $\begin{array}{l}\text { Pin } 6 \\
\text { PWM }\end{array}$ & $\begin{array}{l}\text { Pin } 7 \\
\text { PWM }\end{array}$ & Pin 8 PWM & $\begin{array}{l}\text { Pin } 11 \\
\text { PWM }\end{array}$ & Pin 9 PWM & Pin 10 PWM & $\begin{array}{l}\text { Motor } \\
\text { Kanan }\end{array}$ & $\begin{array}{c}\text { Motor } \\
\text { Kiri }\end{array}$ \\
\hline Maju & 85 & Low & High & 85 & Low & High & $\mathrm{CW}$ & $\mathrm{CW}$ \\
\hline Mundur & -75 & High & Low & -75 & High & Low & $\mathrm{CCW}$ & $\mathrm{CCW}$ \\
\hline Belok kiri & -90 & High & Low & 90 & Low & High & $\mathrm{CCW}$ & $\mathrm{CW}$ \\
\hline $\begin{array}{l}\text { Belok } \\
\text { kanan }\end{array}$ & 80 & Low & High & -80 & High & Low & $\mathrm{CW}$ & $\mathrm{CCW}$ \\
\hline Stop & 0 & Low & Low & 0 & Low & Low & Stop & Stop \\
\hline Putar kiri & -85 & High & Low & 85 & Low & High & $\mathrm{CCW}$ & $\mathrm{CW}$ \\
\hline Putar kanan & 90 & Low & High & -90 & High & Low & $\mathrm{CW}$ & $\mathrm{CCW}$ \\
\hline
\end{tabular}

D.Flowchart Sistem

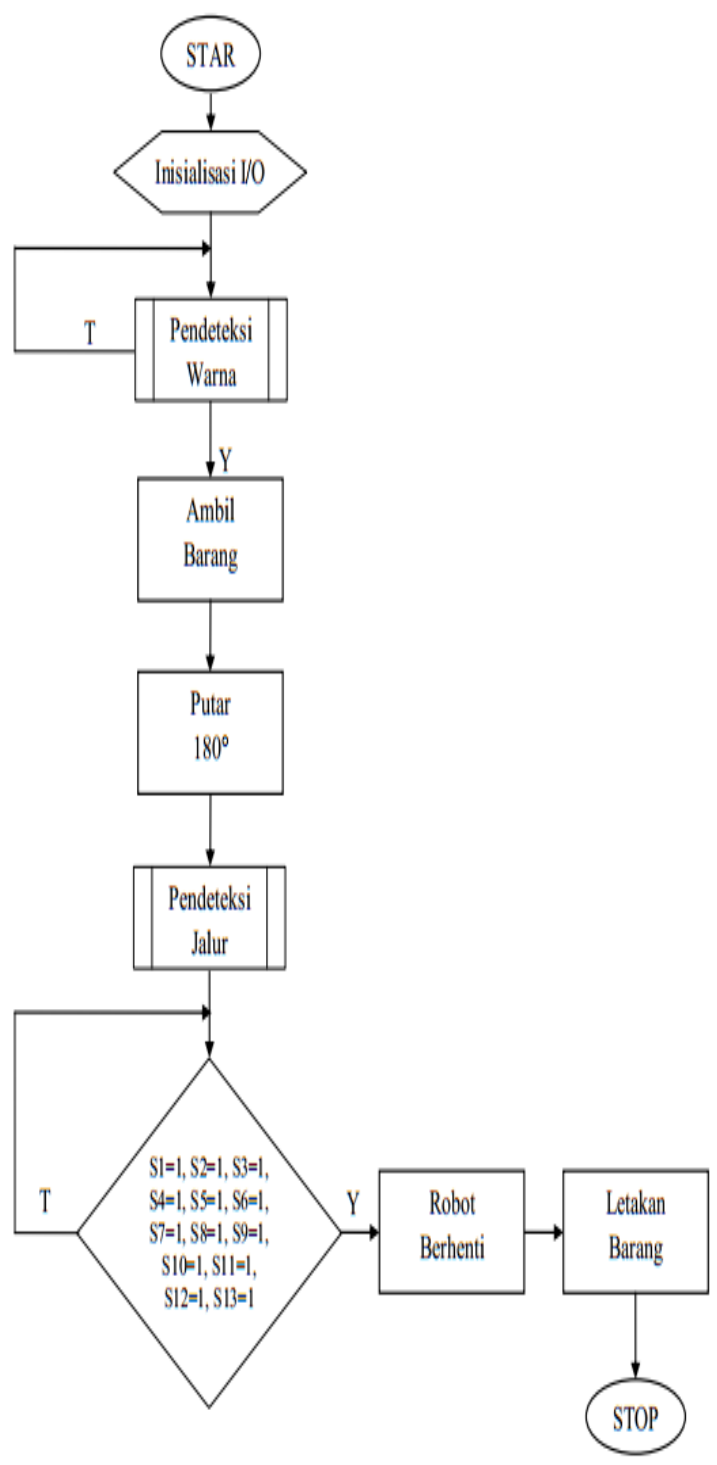

Gambar 7. Flowchart sistem
E. Flowchart Pendeteksi Warna

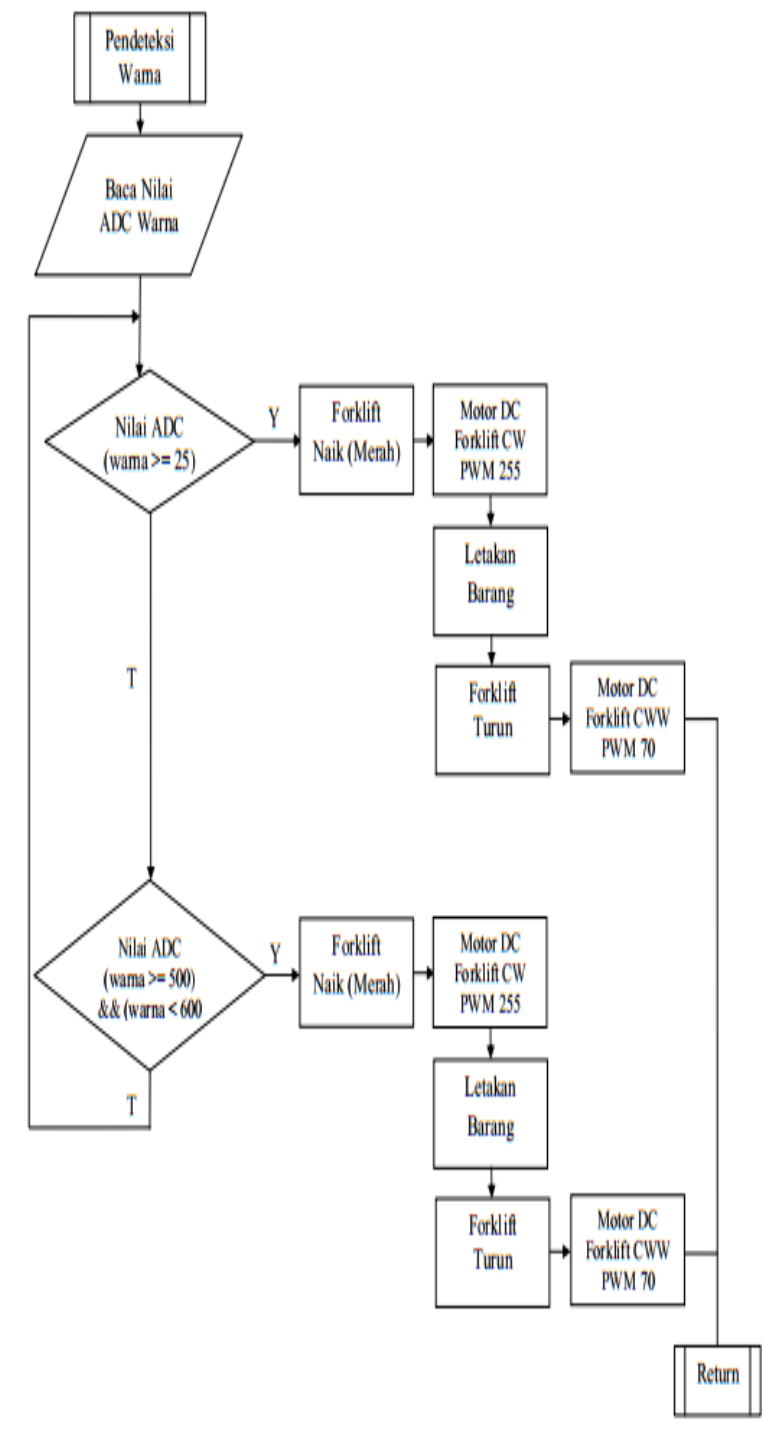

Gambar 8. Flowchart pendeteksi warna 


\section{F. Flowchart Pendeteksi Jalur}

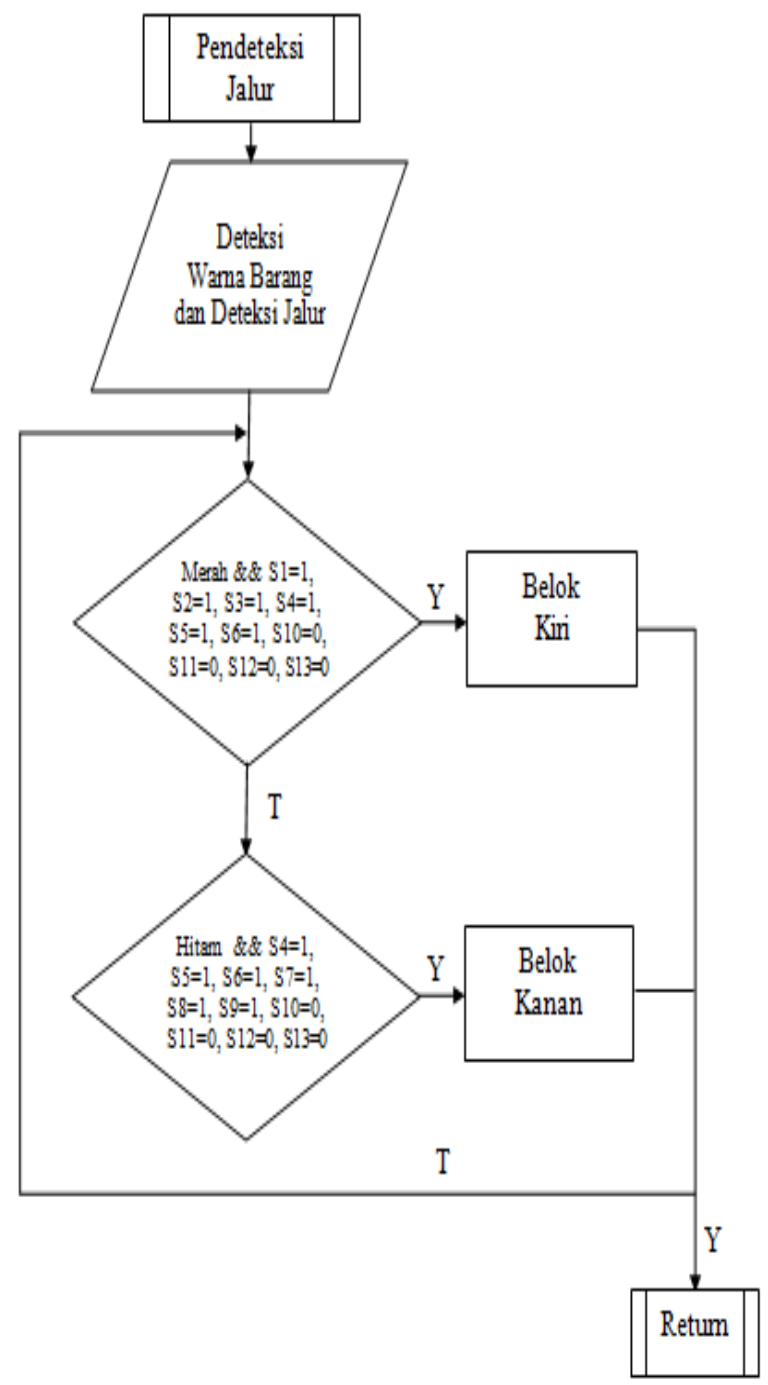

Gambar 9. Flowchart pendeteksi jalur

Keterangan :

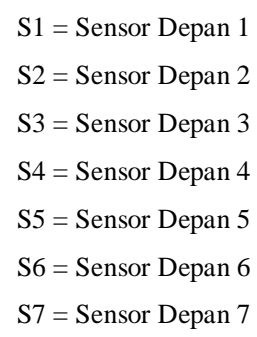

$\mathrm{S} 8=$ Sensor Depan 8

S9 = Sensor Depan 9

$\mathrm{S} 10=$ Sensor Samping Kiri 1

S11 = Sensor Samping Kiri 2

S12 = Sensor Samping Kanan 1

S13 $=$ Sensor Samping Kanan 2

\section{G. Perancangan dan Pembuatan Mekanik}

Alat yang dibuat merupakan miniatur forklift dari sebuah peralatan yang sesungguhnya. Rancangan fisik dari alat dapat dilihat pada gambar 10 berikut:

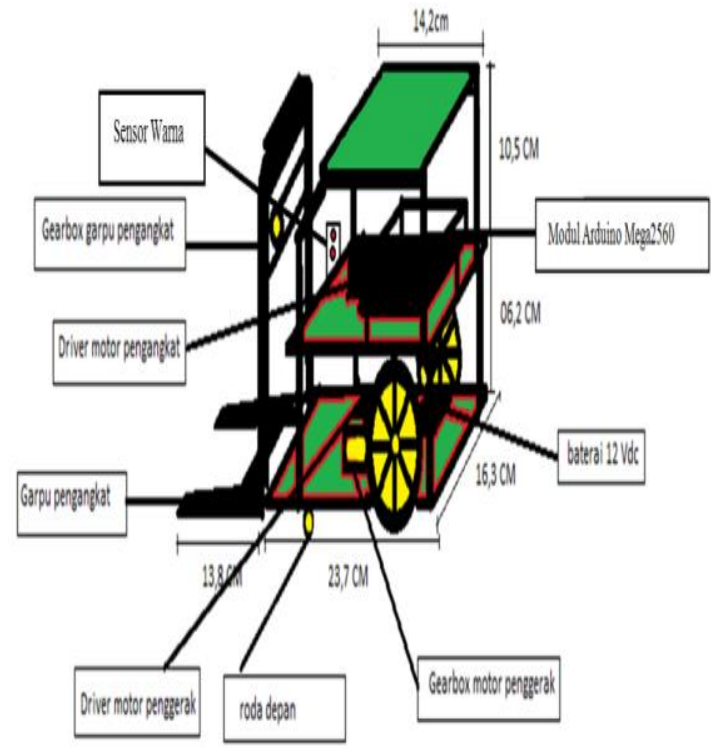

Gambar 10. Rancangan Fisik Robot Forklift

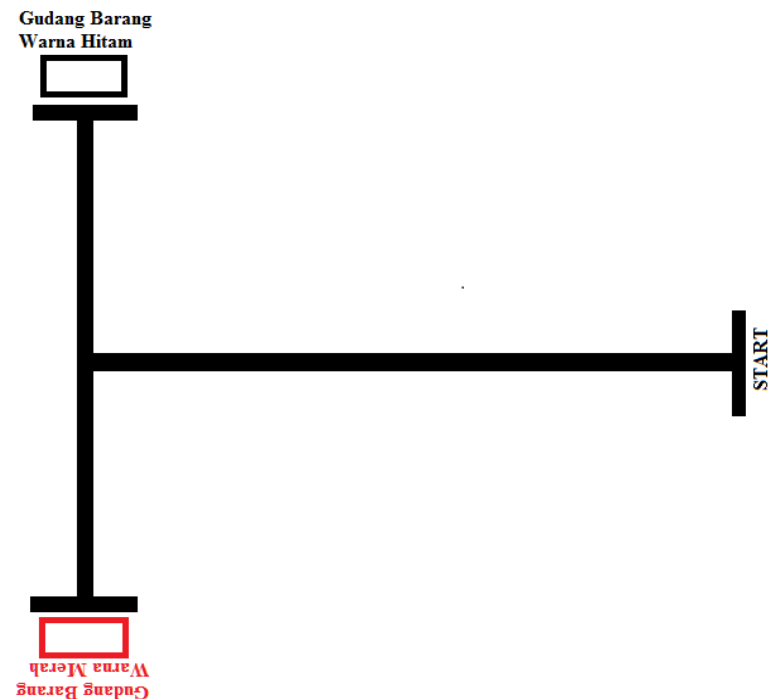

Gambar 11. Desain Jalur Robot Forklift

\section{HASIL DAN PEMBAHASAN}

Pengujian dari robot forklift dengan pemindai barang berdasarkan warna ini dilakukan dengan mendapatkan data ADC dari masing-masing warrna barang. Pengujian driver motor DC, dilakukan untuk mengetahui lebar sinyal yang dinyatakan dengan pulsa berdasarkan PWM yang digunakan pada motor DC.

\section{A. Pengujian dan Analisa pada Bagian Pendeteksi Jalur}

Titik pengukuran pada sensor Rangkaian Sensor Garis pada pin A0-A8, A9-A10 dan A11-A12. Dari hasil pengukuran dan pengujian pada bagian sensor garis depan dapat dianalisa bahwa tegangan yang didapat pada saat sensor melewati jalur hitam yaitu 
berkisar 2,53 V sampai 3,43 V. Pada saat sensor diluar jalur hitam maka tegangan yang didapat yaitu $0,40 \mathrm{~V}$ sampai 1,3 V, seperti terlihat pada gambar 12 .

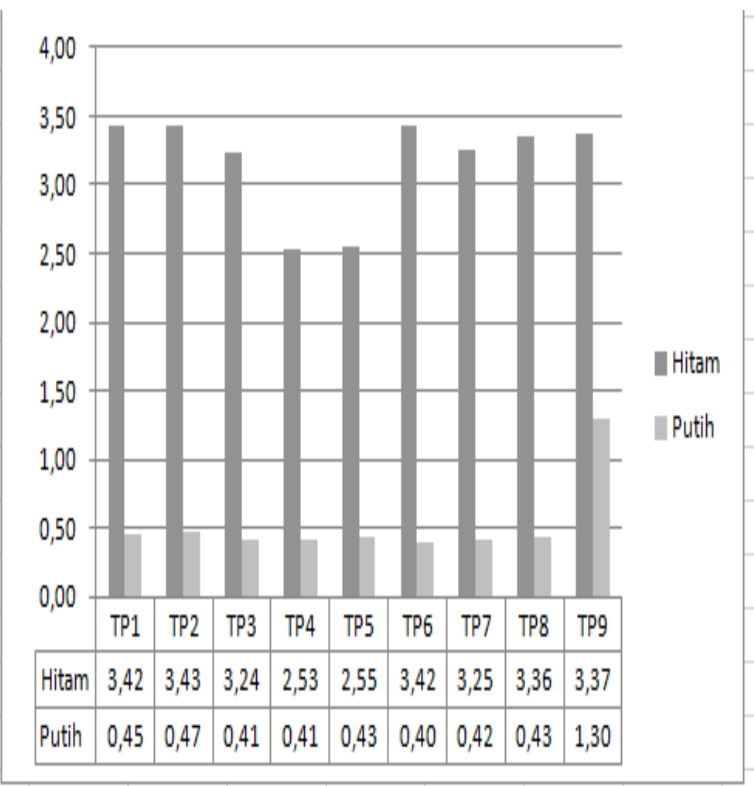

Gambar 12. Hasil Pengukuran sensor garis depan

pengukuran dan pengujian pada bagian sensor garis samping kiri dan kanan hasil yang didapat sama dengan bagian sensor depan jalur hitam akan terbaca pada range tegangan $2,53 \mathrm{~V}$ sampai denan $3,43 \mathrm{~V}$ sedangkan jalur putih $0,40 \mathrm{~V}$ sampai $1,3 \mathrm{~V}$.

\section{B. Pengujian dan Analisa pada Bagian Pendeteksi Warna Barang}

Hasil pengukuran pada rangkaian sensor cahaya photodioda pendeteksi warna barang ditunjukkan oleh pada tabel 4.

Tabel 4. Hasil Pengukuran Pendeteksi Warna Barang

\begin{tabular}{cc}
\hline $\begin{array}{c}\text { Warna } \\
\text { Barang }\end{array}$ & $\begin{array}{c}\text { TEGANGAN } \\
\text { (VOLT) }\end{array}$ \\
\hline Merah & $0,13 \mathrm{~V}$ \\
\hline Hitam & $2,48 \mathrm{~V}$ \\
\hline Ungu & $0,3 \mathrm{~V}$ \\
\hline Biru & $2 \mathrm{~V}$ \\
\hline Hijau & $0,18 \mathrm{~V}$ \\
\hline Jingga & $1,7 \mathrm{~V}$ \\
\hline $\begin{array}{c}\text { Tidak Ada } \\
\text { Barang }\end{array}$ & $4,98 \mathrm{~V}$ \\
\hline
\end{tabular}

Setelah dilakukan pengujian terhadap jarak barang dengan sensor cahaya photodioda untuk mengetahui warna dari barang tersebut didapatkan data sebagai berikut:
Tabel 5. Jarak Warna Barang yang Dapat Dideteksi

\begin{tabular}{cc}
\hline Jarak & Sensor warna \\
\hline $15 \mathrm{~cm}$ & $\begin{array}{c}\text { Warna Tidak } \\
\text { Terdeteksi }\end{array}$ \\
\hline $10 \mathrm{~cm}$ & $\begin{array}{c}\text { Warna Tidak } \\
\text { Terdeteksi }\end{array}$ \\
\hline $5 \mathrm{~cm}$ & $\begin{array}{c}\text { Warna Tidak } \\
\text { Terdeteksi }\end{array}$ \\
\hline $3 \mathrm{~cm}$ & Warna Terdeteksi \\
\hline
\end{tabular}

Dari tabel 5 dapat dilihat, warna yang dapat terdeteksi oleh robot pada jarak 3-4 cm sedangkan lebih dari 5 $\mathrm{cm}$ warna tidak dapt terdeteksi.

C.Pengujian dan Analisa pada Bagian Penggerak Forklift

Selanjutnyaa dilakukan pengujian pada rangkaian bagian penggerak forklift bisa dilihat pada gambar 13 dibawah ini:

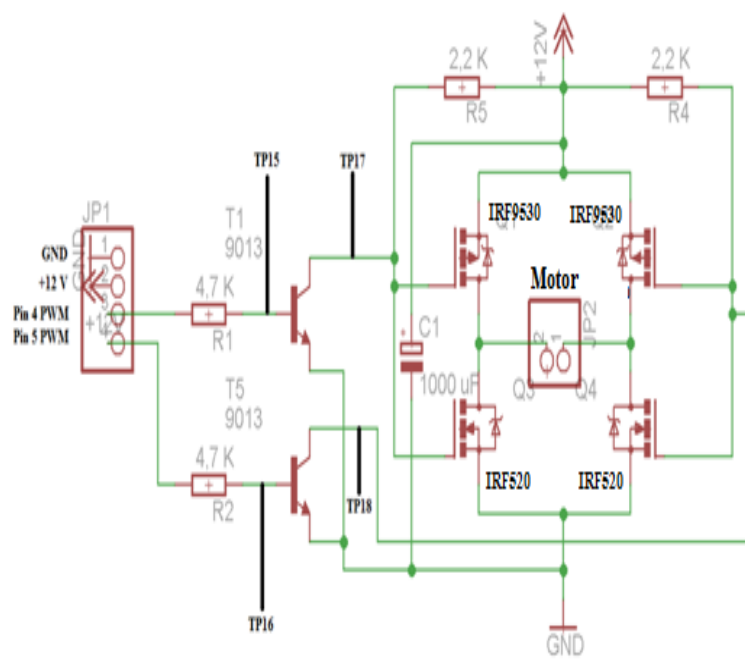

Gambar 13. Titik Pengukuran dan pengujian Rangkaian Bagian Penggerak Forklift

Hasil pengukuran tegangan rangkian driver motor DC pada saat diberi trigger berupa PWM dapat dilihat pada tabel 6 berikut ini.

Tabel 6. Hasil Pengujian Rangkaian Driver Motor Penggerak Robot Forklift

\begin{tabular}{cccccc}
\hline $\begin{array}{c}\text { TP15 } \\
\text { (Volt) }\end{array}$ & $\begin{array}{c}\text { TP16 } \\
\text { (Volt) }\end{array}$ & $\begin{array}{c}\text { TP17 } \\
\text { (Volt) }\end{array}$ & $\begin{array}{c}\text { TP18 } \\
(\text { Volt })\end{array}$ & $\begin{array}{c}\text { Kondisi } \\
\text { Motor }\end{array}$ & Forklift \\
\hline $0,82 \mathrm{~V}$ & $0 \mathrm{~V}$ & $0 \mathrm{~V}$ & $\begin{array}{c}11,22 \\
\mathrm{~V}\end{array}$ & $\mathrm{CW}$ & Naik \\
\hline $0 \mathrm{~V}$ & $\begin{array}{c}0,20 \\
\mathrm{~V}\end{array}$ & $\begin{array}{c}11,38 \\
\mathrm{~V}\end{array}$ & $0 \mathrm{~V}$ & CCW & Turun \\
\hline
\end{tabular}

Hasil pengukuran tegangan pada rangkaian driver motor Pengangkat pada saat diberi beban dalam satuan gram dapat dilihat pada tabel 7 berikut ini: 
Tabel 7. Hasil Pengujian Robot Forklift dengan Menggunakan Beban

\begin{tabular}{|c|c|c|c|c|c|c|c|c|}
\hline Berat & $\begin{array}{c}\text { Pin } \\
4\end{array}$ & $\begin{array}{c}\text { Pin } \\
5\end{array}$ & $\begin{array}{l}\text { TP15 } \\
\text { (Volt) }\end{array}$ & $\begin{array}{l}\text { TP16 } \\
\text { (Volt) }\end{array}$ & $\begin{array}{l}\text { TP17 } \\
\text { (Volt) }\end{array}$ & $\begin{array}{l}\text { TP18 } \\
\text { (Volt) }\end{array}$ & $\begin{array}{l}\text { Arah } \\
\text { Putar } \\
\text { Motor }\end{array}$ & Kondisi \\
\hline \multirow{2}{*}{$150 \mathrm{~g}$} & 255 & 0 & $\begin{array}{c}0,80 \\
\mathrm{~V}\end{array}$ & $0 \mathrm{~V}$ & $0 \mathrm{~V}$ & $\begin{array}{c}11,36 \\
\mathrm{~V}\end{array}$ & $\mathrm{CW}$ & \multirow{2}{*}{$\begin{array}{c}\text { Forklift } \\
\text { dapat } \\
\text { mengangkat } \\
\text { beban }\end{array}$} \\
\hline & 0 & 70 & $0 \mathrm{~V}$ & $\begin{array}{c}0,22 \\
\mathrm{~V}\end{array}$ & $\begin{array}{c}11,38 \\
\mathrm{~V}\end{array}$ & $0 \mathrm{~V}$ & $\mathrm{CCW}$ & \\
\hline \multirow[b]{2}{*}{$250 \mathrm{~g}$} & 255 & 0 & $\begin{array}{c}0,80 \\
\mathrm{~V}\end{array}$ & $0 \mathrm{~V}$ & $0 \mathrm{~V}$ & $\begin{array}{c}11,36 \\
\mathrm{~V}\end{array}$ & $\mathrm{CW}$ & \multirow{2}{*}{$\begin{array}{c}\text { Forklift } \\
\text { dapat } \\
\text { mengangkat } \\
\text { beban } \\
\text { namun } \\
\text { motor DC } \\
\text { bekerja } \\
\text { lambat }\end{array}$} \\
\hline & 0 & 70 & $0 \mathrm{~V}$ & $\begin{array}{c}0,22 \\
\mathrm{~V}\end{array}$ & $\begin{array}{c}11,38 \\
\mathrm{~V}\end{array}$ & $0 \mathrm{~V}$ & $\mathrm{CCW}$ & \\
\hline \multirow{2}{*}{$300 \mathrm{~g}$} & 255 & 0 & $\begin{array}{c}0,80 \\
\mathrm{~V}\end{array}$ & $0 \mathrm{~V}$ & $0 \mathrm{~V}$ & $\begin{array}{c}11,36 \\
\mathrm{~V}\end{array}$ & $\mathrm{CW}$ & \multirow{2}{*}{$\begin{array}{c}\text { Forklift } \\
\text { tidak dapat } \\
\text { mengangkat } \\
\text { beban }\end{array}$} \\
\hline & 0 & 70 & $0 \mathrm{~V}$ & $\begin{array}{c}0,22 \\
\mathrm{~V}\end{array}$ & $\begin{array}{c}11,38 \\
\mathrm{~V}\end{array}$ & $0 \mathrm{~V}$ & $\mathrm{CCW}$ & \\
\hline
\end{tabular}

Rangkaian driver motor yang digunakan berfungsi untuk menggerakan motor yang mempunyai arus besar. Driver motor ini mampu menggerakan motor berputar 2 arah ( $C W$ dan $C C W$ ) ketika salah satu transistor mendapatkan bias (tegangan). Motor akan berputar $C W$ (Clock Wise) ketika transistor T1 mendapatkan picuan yang berupa tegangan dari mikrokontroler. Saat transistor T1 mendapat bias maka tegangan pada VCE (TP17) akan turun. Ketika tegangan VCE turun maka arus akan mengalir dan mengaktifkan rangkaian $\mathrm{h}$ - bridge. Kemudian arus akan mengalir menuju katoda motor. Akibatnya tegangan pada motor yang sebelumnya 0 Volt (TP18) akan naik dan motor akan berputar CW. Sedangkan saat transistor T5 mendapatkan picuan dari mikrokontroler maka tegangan VCE (TP18) akan turun. Pada kondisi ini arus akan mengalir dan mengaktifkan h-bridge. Selanjutnya h-bridge akan mengalirkan arus ke anoda motor dan motor akan berputar CCW.

Dari hasil pengukuran didapatkan analisa bahwa semakin besar lebar pulsa maka tegangan yang diberikan terhadap motor juga semakin besar. Saat motor diberikan nilai PWM di bawah 255 maka motor sebenarnya mengalami on dan off sesuai dengan nilai PWM nya. Besarnya nilai PWM yang diberikan mempengaruhi tegangan ouput driver yang mengakibatkan motor berputar lambat dan cepat. Semakin besar nilai PWM yang diberikan maka semakin besar juga nilai tegangan output pada motor. Dari data tersebut dapat disimpulkan bahwa semakin cepat putaran pada motor DC maka lebar pulsa juga semakin besar selain itu cepat lambatnya putaran motor DC juga berbanding lurus dengan dutyciclenya, dutycycle $100 \%$ berarti sinyal tegangan pengatur motor dilewatkan seluruhnya, jika tegangan $12 \mathrm{~V}$ maka motor akan mendapat tagangan sebesar $12 \mathrm{~V}$ juga pada basis transistor.

\section{KESIMPULAN}

1. Robot forklift memanfaatkan sensor garis sebagai pembaca jalur yang akan dilewati, jalur yang dilewati adalah jalur berwarna hitam. 2,53V sampai denan 3,43 V

2. Penggerak forklift meggunakan motor DC dengan PWM 255 disaat forklift naik dan PWM 70 saat forklift turun.

3. Sensor cahaya photodioda berfungsi untuk mendeteksi warna barang yang akan diangkat oleh forklift dan warna barang terdiri dari dua warna yaitu merah dengan data ADC yang terbaca 26 dan hitam dengan data ADC yang terbaca 512.

4. Jarak sensor warna dapat mendeteksi warna barang yaitu $3 \mathrm{~cm}$.

\section{REFERENSI}

[1] Rahmiyati, P., Firdau, G., Fathorrahman, N., 2014, Implementasi Sistem Bluetooth Menggunakan Android dan Arduino untuk Kendali Peralatan Elektronik, Jurnal ELKOMIKA, No.1, Vol. 2, Hal 1-14.

[2] Aulia Rahman. Pemodelan Robot Beroda Menggunakan Umpan Balik Giroskop. Jurnal Rekayasa Elektrika Vol. 12, No. 2, Agustus 2016, hal. 67-72

[3] Ery Safrianti, Rahyul Amri dan Septian Budiman. Prototype Robot Pemadam Api Beroda Menggunakan Teknik Navigasi Wall 
Follower. Jurnal Rekayasa Elektrika Vol. 10, No. 2, Oktober 2012 , hal: $83-91$

[4] Firmansyah, Yuwaldi Away, Rizal Munadi, Muhammad Ikhsan, ,Ikram Muddin. Perancangan Lengan Robot 5 Derajat Kebebasan dengan Pendekatan Kinematika. Jurnal Rekayasa Elektrika Vol. 11, No. 2, Oktober 2014, hal. 69-72

[5] C. Perez-Montenegro, E. Canuto, A. Cardenas-Olaya and W. Acuna-Bravo, "Mobile robot modelling and autonomous guidance," Automatic Control (CCAC), 2015 IEEE 2 ${ }^{\text {nd }}$ Colombian Conference on, Manizales, 2015, pp. 1-6.
[6] P. Tan and Z. Cai, "Modelling and Planning of Mobile Robot Navigation Control in Unknown Environment," 2015 International Conference on Computational Intelligence and Communication Networks (CICN), Jabalpur, India, 2015, pp. 1532-1536.

[7] Agung Deni Saputra. 2013. Rancang Bangun Robot Forklift Dengan Bluetooth Sistem Android

[8] Kadir,Abdul.2013. Panduan praktis mempelajari aplikasi mikrokontroler dan pemrograman Menggunakan arduino;Andi Yogyakarta.

[9] Tugas akhir. Universitas mercu buana. Forklift,(Online), $\begin{array}{llll}\text { (diakses } & 25 & \text { agustus }\end{array}$ 